\title{
On the genealogy of Lebensraum
}

\author{
C. Abrahamsson \\ Department of Human Geography, Lund University, Lund, Sweden \\ Correspondence to: C. Abrahamsson (abrahamsson28@gmail.com)
}

Received: 1 February 2013 - Revised: 15 April 2013 - Accepted: 16 April 2013 - Published: 30 May 2013

\begin{abstract}
The aim of this paper is to outline a genealogy of the concept of Lebensraum. It will focus on the way that Darwinian evolutionary thought was translated into 19th Century German geography, particularly in the work of Friedrich Ratzel and his formulation of the concept of Lebensraum. The paper argues that the Ratzelian Lebensraum must be viewed as a concept aimed towards a synthesis between biogeography and anthropogeography. The paper will also trace how the Ratzelian Lebensraum came to play a vital part in Rudolf Kjellén's later formulation of an organic theory of the state. Here the paper will focus specifically on Kjellén's organic taxonomy of the political system. The paper will end with a short discussion on the synthetic aspects of the Lebensraum concept, focusing on the seemingly divergent ways that the Lebensraum concept was mobilised within National socialist ideology and planning.
\end{abstract}

\section{Introduction}

Writing in the immediate aftermath of World War II, professor Carl Troll of Bonn University, a leading expert on mountain geology, penned a paper with the explicit aim of disentangling scientific geography from what he described as the pseudo-scientific geography of the Third Reich. Originally written as a key note for the German geography days and published in Erdkunde: Archiv für Wissenschaftliche Geographie, a translated version of the paper appeared the following year in the Annals of the Association of American $\mathrm{Ge}$ ographers as "Geographic Science in Germany During the Period 1933-1945: A Critique and Justification". According to Troll, the active mobilisation of geographical concepts by the National socialists had seriously damaged the disinterested status of non-ideological science. In Troll's view this was particularly true of the Ratzelian Lebensraum. In its original meaning Troll exclaims that Lebensraum is, more or less, synonymous with man's biological "habitat". A conflation had, Troll argued, taken place between the scientific meanings of the term with its political connotations, a process in which geographers had been eager participants, accepting this "enlarged meaning of the term and [speaking] readily of geographical Raum and Lebensraum of peoples, even in cases where no real three-dimensional distribution was implied." German geographers were active in coining neol- ogisms, such as, "Lebensspielraum", and designating areas with terms such as "native", "foreign", "actual" and "potential" Lebensraum. Furthermore, Troll's evaluation of the appropriation of the term was invested in seeking to define "the ideal form of the Reich and of the Großraum organization of adjacent areas" and an engineering and calculation geared towards "explor[ing] the way to a perfect Lebensraum" (Troll, 1949:115).

We know now that the disentangling that Troll wanted to accomplish between the scientific meaning of Lebensraum and its pseudo-scientific connotations and usages was, in the end, unsuccessful. Lebensraum is still, in the public discourse, a disgraced concept, and rightly so. The aim of this article is not to argue for a revitalisation of its usage or incorporation into contemporary discourse. Rather, its aim is to place the renewed interest in geography concerning the relation between politics, biology and space in dialogue with a previous era's infatuation with the same relation. Furthermore, a rethinking of the notion Lebensraum and the potential risks and pitfalls that come with conflating the political and the biological becomes particularly timely in light of geography's recent turn towards a theorizing of life's intertwinement with space. Much, if not all, of this work is done without any reference to the geography of Ratzel. Though, ironically, much of this work hinges on the work of his contemporaries - e.g. Jakob von Uexküll and Gabriel Tarde (for 
a discussion of, among others, von Uexküll in this context, see Harrington, 1996).

In relation to this it is fascinating to notice the similarities or, perhaps, more accurately elective affinities between the Weltanschauung of the late 19th century and contemporary concerns around matter, life, ecology, immanence, environment and evolution. The ways that these concerns resonate within political and social discourses are of course different. Of particular relevance here are the ways that contemporary geography has undergone a semantic shift in recent years towards a reinvigorated vitalism or vital materialism (see for example Whatmore, 2002, 2006; Thrift, 2004, 2007). This semantic shift within contemporary geography cannot easily be assembled under one theoretical heading though it does have some shared trajectories. A key meditator in this regard has been the work of Gilles Deleuze, particularly through his readings and interpretations of among others Jakob von Uexküll, Gabriel Tarde, Henri Bergson and Baruch Spinoza. The way that these writers have been taken up is characterised by a lack of historical and geographical contextualisation. Furthermore, there has been a lacunae relating to the ethical and political consequences that come with translating vitalist thought into political thought. This lacunae becomes particularly troubling when we begin to consider these writers in their different contexts and the ways that they often attempted a synthesis between political thought/practice and vitalist thought. These histories are almost completely absent in this semantic shift towards an affirmative vitalism in contemporary geography (Abrahamsson, 2011).

Part of the work that this paper attempts to accomplish is to demonstrate how geography has had a long and often troubling tradition of drawing together the ecological with the political. In doing so it tries to draw attention to a set of translational shifts within European geographies associated with the concept of Lebensraum. The paper will do so by emphasising, on one the hand, how mid-19th century German geography entered into a sustained dialogue with Darwinian thought and, on the other hand, how during a later stage this involved a set of linguistic and contextual shifts. There are several lacunae and caesuras in these shifts. Any translation will naturally involve an element of Chinese whispers. Something will always be lost while, perhaps, something else is gained in the movement necessary for a translation to take place. At stake here, however, is the question of how an entire tradition has been ceded while at the same time we are still apparently living with some of the same questions posed by that same tradition. It is not my intention to return to a lost tradition for tradition's own sake. It is, however, important to consider the question of how a specific geographical imagination became intertwined with, on one hand, a specific biological imagination and, on the other, a specific political imagination gathered or drawn together under the holistic concept of Lebensraum. As I have already claimed there are strong affinities between the world view of the late 19th century and our contemporary investment in ecological thought.
Given these affinities there is a need to be very careful when we translate theories and imaginations. I will return to these affinities in the conclusion, though it should already here be made clear that although Troll's attempt to rescue the concept Lebensraum failed, many of the imaginations associated with the concept remained.

\section{The Darwinian influence on German geography}

Before we proceed to investigating the formation of the concept of Lebensraum in Ratzel and Kjellén, it is important to give a brief overview of the geographical and historical context in which Ratzel's ideas emerged. I will argue that the key event influencing and to some degree shaping German geographical thought during the second half of the 19th century was the publication of Charles Darwin's On the Origin of Species by Means of Natural Selection, or the Preservation of Favoured Races in the Struggle for Life. Of particular interest here is the fact that The Origin of Species appeared in German translation in 1860, just months after the original book was published (see Gliboff, 2008). The publication of The Origin of Species didn't go unnoticed by the younger generation of German geographers at the time. Oscar Peschel, Ratzel's predecessor at the chair of geography in Leipzig, began promoting Darwinian ideas immediately after Origin of Species appeared, most noticeably in a review in the journal for which he was the editor at the time, Das Ausland. Here Peschel develops the term Lebensraum in order to translate Darwin's hypothesis into geographical terms. For Peschel the notion of Lebensraum drew attention to the fact that, according to him, natural selection was always already a telluric selection (Peschel, 1860). Without going into detail, suffice to say that the reception of Darwinian thought into the German sphere was widely divergent. Often, though not always, the battle lines were drawn along ideological lines, Darwinism being associated mainly with a liberal-universalist ideology, being associated with British civilisation distinct and different from Germanic kultur. Another, equally important, dividing line concerning the reception of Darwinism was that between monogenism - positing a common ancestry of man - and polygenism - positing that the races of man are of different lineages. These two battle lines are of importance when we want to understand the reception of evolutionary thought in German geography (see further Zimmerman, 2001; Richards, 2008; and Livingstone, 2005; Smith, 1991).

The major impetus from Darwinian thought on the geographical imagination of the late nineteenth century was the idea of evolutionary change. I will not give a full account of the reception of Darwin's theory in German geography. It is, however, particularly important to draw attention to two conditions that, one can argue, led to its rapid acceptation and translation into geographical thought. Firstly, the reception of Darwin must be understood in relation to the nascent national project of the second Reich, which saw Germany as being 
left behind in the colonial race. The colonial project was simultaneously conceived as answering to economical and demographical challenges (Smith, 1986). The demographic question, or the question of overpopulation, was, as Woodruff Smith has argued, a specific concern in the formation of German colonial politics. A recurring argument was that Germany needed to establish colonies to create space for its growing population. In this context the emphasis that Darwinian thought put on change and evolution could serve as a scientific explanation and rationale for the need for colonial expansion - a project in which the leading geographers in Germany eagerly participated (Bassin, 1987; Danielsson, 2008; Smith, 1986). A political and social interpretation of Darwinian evolutionary thought could also provide a scientific rationale for the subjugation and extermination of indigenous populations (Weikart, 2003; Danielsson, 2009). Oscar Peschel argued that the disappearance of lesser races was: "the historical course. If we view it with the eye of a geologist, and indeed a geologist which accepts the Darwinian theory, we must say that this extinction [of human races] is a natural process, like the extinction of secondary animal and plant forms" (Peschel quoted in Weikart, 2003:276). Secondly, the reception of Darwinian thought in German geography can also be explained by the formation of many of the leading German geographers at the time. Friedrich Ratzel was originally trained as a zoologist and geologist and Alfred Kirchhoff had attended lectures with Ernest Haeckel. Furthermore, Ratzel had already written an early exposition entitled Sein und Werden der organischen Welt, the aim of which had been to promote and popularize Darwinian thought, and Kirchhoff's final posthumously published book was given the revealing title Darwinismus angewandt auf Volker und Staaten [Darwinism Applied to Peoples and States] (1910). In this work Kirchhoff argued that in: "the struggle for existence between the peoples, [which] causes the extermination of the crude, immoral hordes... Not the physically strongest, but the [morally] best ones triumph. If there were not a diversity of peoples, if there were no international rivalries, where would be the guarantee for the preservation of the fitness of the peoples, not to mention for the progress of humanity?" (Kirchhoff quoted in Weikart, 2003:274).

\section{The Ratzelian Lebensraum - between biogeography and anthropogeography}

In Politische Geographie, Ratzel argues that biological differentiation is a growth phenomenon; as such it gives rise to the spatial division of labour that follows the growth of the organism, a growth that centres certain functions in specific parts of the organism, functions that are governed by a central organ. But whereas for the biologist the differentiation that is expressed in the spatial extension of the organism is the last of the laws of differentiation, the reverse is true for the political geographer. For the political geographer, the spatial extension of the state is the condition that all other conditions are grounded (Ratzel, 1903:75-76). Ratzel's most developed formulation of the concept of Lebensraum is found in Der Lebensraum: Eine biogeograpische Studie (Ratzel, 1901). The genesis of Lebensraum had, however, been present in Ratzel's work throughout the 1890s, particularly in his Politische Geographie. Ratzel described Lebensraum as a concept that gathers together the biological, geographical and anthropological conditions of a given environment. As a synthetic concept, its aim was to theorize the biological conditions and changes within a delimited area to describe the relationship between a species and a particular environment. Thus, the Lebensraum is "the geographical surface area required to support a living species at its current population size and mode of existence" (Smith, 1980:53). As such, any increase or decrease in the population will necessarily change the spatial needs of the population. For Ratzel, the Lebensraum was of fundamental significance when the scientist wants to understand the spatial characteristics of life, as life cannot be separated from its spatial requirements. In Ratzel's own words: "[Every] new form of life needs space in order to come into existence, and yet more space to establish and pass on its characteristics" (Ratzel quoted in Bassin, 1987:477). For Ratzel the same laws that governed organic differentiation governed the differentiation of human societies and states. The focus on overpopulation and its detrimental effects was common in nineteenth century social science. The most important figure in these debates was Malthus. Though, as Mark Bassin argues, the conclusions drawn by Ratzel and his contemporaries: "were diametrically opposed to those of Malthus. For while the latter was concerned that the population of a country, should simply not be allowed to grow beyond that country's nutritional capacity... it was canonical in the view of the Social Darwinists that a vigorous increase of population was one of the most important indications of a nation's health and vitality." (Bassin, 1987:478). Ratzel's rejection of the Malthusian dictum regarding population control can partly be explained by the influence on him by the zoologist Moritz Wagner. In 1868 Wagner published a book, the aim of which was to develop Darwin's theories in their proper geographical context. In Die Darwinische Theorie und das Migrationsgesetz der Organismen Wagner put forward "a 'migration theory' according to which all living species migrated over the earth's surface as a natural consequence of life. Natural selection occurred when migrating species came into conflict over territory" (Smith, 1980:67).

In Ratzel's political geography the question of continuous expansion was crucial in the rise of great powers and the vitality of individual states. He conceptualised this expansion as taking place on a planetary scale, a scale in which the partial space of any given nation-state is always dependant on the whole. According to Ratzel: "The given space of every age has decided how far countries have had to expand in order to become in reality 'world powers', i.e., to span the earth; and in this general process, every single country, even 
the smallest, has had its position continually modified by the growth of the whole. Since the size of the earth's surface sets limits to this development, the zenith can be reached by only a few states at the same time" (Ratzel, 1897:298-299). The problem of the limitations of the earth's surface, which is a given condition, poses a major problem as life itself doesn't necessarily remain static. Ratzel argued that the Darwinians had overseen this elemental fact when they saw the struggle over life as the foundational explanation behind evolutionary processes. For him the struggle over life is always already a struggle over space. In Ratzel's words: "[t]he much misused, and even more misunderstood expression 'the struggle for existence' really means first of all a struggle for space. For space is the very first condition of life, in terms of which all other conditions are measured, above all sustenance" (Ratzel, 1901:168, my translation).

The relation between Ratzel's political geography and his biogeographical formulation of the concept of Lebensraum are thus intertwined to the degree that they cannot be understood apart from each other. The relative need for territorial expansion of states and the limits set by this expansion by the absolute space of the earth's surface will always create a struggle for space, a struggle for space that results directly from the fundamental tension between the fixity of the earth and the becoming of life. According to Ratzel the only way a strong and vital state can achieve a semblance of equilibrium is through continuous expansion. The earlier Malthusian thesis of limiting population growth was therefore not an option (Bassin, 1987:478). Ratzel argued that: "All checks to increase of population have an incalculably far-reaching effect; they prevent any influx of men and capital, and, by invading the natural course of increase, injure the health and morality of the community, and, in general, place the future of the people on too narrow a basis. This isolation, however, from the nature of things, cannot be lasting, and as soon as it is broken through, the people, whose progress has been arrested, are exposed in consequence" (Ratzel, 1898:378).

For Ratzel, the exact boundaries of the state's territory and of its Lebensraum are always relative to the size of their populations and the metabolic requirements of this population. Expansion is then for Ratzel always connected to the growth of the population and its ensuing metabolic needs - as in the case of the organism itself. As a result of a growing need for Lebensraum or territory, the same space would be struggled over by different groups. In his view this is equally true independent of species. In Rudolf Kjellén's words: "Vital states, occupying a limited space, are governed by the categorical political imperative to enlarge their territory, through colonisation, annexation or conquest" (Kjellén, 1916:67, my translation).

\section{Rudolf Kjellén and the State as life form}

Although not a student of Ratzel, the Swedish political scientist Rudolf Kjellén can be described as his most prominent disciple. Kjellén came to function as the translator and synthesiser of Ratzel's ideas into a language of organic state theory. Kjellén, perhaps even more then Ratzel, has been described as the primary source of inspiration for the geopolitical school of Karl Haushofer (Holdar, 1992; Elvander, 1956; Thermaenius, 1937; see also Haushofer (Ed.), 1932). There are several ways to explain the intermediary position that Kjellén came to occupy between Ratzel and Haushofer. Firstly, Kjellén's work was, as we will see, characterised by a desire to empirically "test" the Ratzelian Lebensraum hypothesis on actual great powers - both contemporary and historical states. Secondly, he wanted to create a more precise terminology that could be mobilised when the geopolitical scientist wanted to analyse a particular state. Thirdly, and perhaps most importantly, Kjellén was far more active in state politics than Ratzel. Given these three considerations he could more easily serve as a model for more the activist tradition of Haushofer's geopolitical school. In a sense we can say that in Kjellén interpretation, Ratzel's ideas underwent an operationalization that could be mobilised by Haushofer.

Here I will focus on the way that the Ratzelian Lebensraum came to function in Kjellén's organic taxonomy of the political system. The argument is that the totality of Kjellén's political taxonomy cannot be overlooked if we are to understand the simultaneous translation into Kjellén's organic state theory of Ratzel's anthropogeography, political geography and biogeography. Kjellén's most important works are Stormakterna: Konturer kring samtidens storpolitik (1905) and Staten som lifsform (1916). Stormakterna is an empirical analysis of the contemporary great powers based on Ratzel's political geography. In Kjellén's own words the book constituted an "empirical experiment", a test of how his system could be applied to an understanding of the vitality of great powers. Stormakterna was hugely influential in Germany, it was published in 24 editions between 1909 and 1934 (Tunander, 2001:451). Rainer Sprengel demonstrates in his Kritik der Geopolitik.: Ein deutscher Diskurs 1914-1944 how Kjellén's geopolitical work is almost immediately both reviewed in the key geographical literature in Germany as well as rapidly translated into German (Sprengel, 1996:27).

A major concern for Kjellén grew out of the contradiction that Ratzel had identified between the stasis of the earth and the incessant movement of life. If one side of the state organism consisted of its territory then the question of the composition of its people still needed to be answered. In Kjellén's words "All subhuman analogies are however made redundant when it comes to the state's ability of spiritual connections... no one is able to move away from ones proper space. There is the power source for each and every one..." (Kjellén, 1916:45, my translation). 
We have already seen that Ratzel had taken from Wagner the idea of migration as a key factor in his anthropogeography. The corollary of this migration theory was that the people of a given state cannot be racially homogenous. Rather, for Ratzel a people gains strength from being racially mixed. Ratzel argued that most "Völker" were racially mixed as a direct result of the migrations that occurred as a natural result of life itself. The problem nevertheless remains for Kjellén. On several occasions Kjellén celebrates, as does Ratzel, the blending of races on the British Isles. For Kjellén the mixing of Celtic, Roman and Germanic racial types is partly the reason why the British Empire had been so successful (Kjellén, 1905:13). A major concern for Kjellén was, as it had been for Ratzel, the migration question. The question of demography and how birth and mortality is related to the rise and decline of great powers was of particular relevance for Kjellén (Kjellén, 1905:173-182). For Kjellén there was a direct relation between the development of the human material [människomassan] of the state and its ability and need to expand (Kjellén, 1905).

In Staten som lifsform Kjellén further refines the Ratzelian idea of the state as an organism; he does so in purely theoretical terms with the explicit aim of creating a taxonomy of state power based, largely, on Ratzel's geography (Kjellén, 1905; Holdar, 1992; Tunander, 2001; Thermaenius, 1937). In Kjellén's taxonomy of different modalities of state politics the geographical is given pre-eminence through the coining of the neologism geopolitics, a term first used by Kjellén in 1899 in an essay on the political borders of Sweden printed in YMER, the year book of the Swedish Society for Anthropology and Geography (Kjellén, 1899). For Kjellén the state "... is attached to its own soil and will die if it loses this connection. ...Here we focus on a trait that the state shares in common with the plant world, like a forest; the state cannot be suspended in the air, it is like the forest bound to a certain soil, from which it gathers sustenance, and under its surface his individual trees braid its roots together" (Kjellén, 1916:44, my translation). This definition is virtually verbatim that of Ratzel: "The state is for us an organism not merely because it is a connection of the living people with the solid earth, but because this connection is through reciprocal influence consolidated to such a degree that they become one and the same, and that one cannot disengage them from one another without destroying the life" (Ratzel, 1897:iii).

For Kjellén the organic state's interdependence with the earth doesn't suffice if we want to fully understand its modalities: the "life form of the state" is characterised by, on one side, its "nationality" and, on the other, its "land" (Kjellén, 1916:83). The state, he argued, is also characterized by eco-politics (economics), demo-politics (demography), socio-politics (social) and krato-politics (laws and constitution, translated in the German edition as Herrschaftspolitik, Kjellén, 1917). Each of these categories is then given further subcategories. Geopolitics is subdivided in the categories topo-politics (the location of the state), morfo-politics (the spatial shape or gestalt of the state) and fysio-politics (the resources of the state); eco-politics is subdivided into emporo-politics (the sphere of economics), autarky-politics and economical-politics; demo-politics is subdivided into ethno-politics (race), pletho-politics (the material of the population) and psyko-politics (the Geist of the people); sociopolitics is subdivided into fylo-politics (the shape of the society) and bio-politics (the life of society); and finally kratopolitics is subdivided into nomo-politics, parxio-politics and arko-politics (see Kjellén, 1916, 1919a, b, c).

Ola Tunander has argued that Kjellén's taxonomy cannot be seen as a mix of these different modalities of the state. Rather, and according to Kjellén, we must view them as a unity, a living organism, that simultaneously incorporates these modalities (Tunander, 2001). Nevertheless, the foundational element of the state is always its natural location its geopolitics. For Kjellén: "Nothing can better demonstrate the consciousness of the modern states intimate connection with the earth than this that he bears the loss of people more lightly than the loss of land" (Kjellén, 1916:47, my translation). For the state the land is always more important than its people: "the state shows more solidarity with the land then with the people... Everything becomes clear with one single word; the Reich [riket] is the state's body. As with any analogy this meant to illuminate, and not to obscure. The Reich [riket] is not a property as the farmers' soil; it is connected to the personality of the state. It is the state itself ... the modern anthropogeography signifies man as a "piece of highly developed soil" ... Also the state "is of soil"; also he is ... a developed piece of soil" (Kjellén, 1916:47, my translation).

As we have seen both Ratzel and Kjellén were keenly aware that the territorial growth of a state cannot be conceptualized or explained from a one dimensional perspective e.g. a growing population's need for sustenance - rather, it has to be analysed from a multidimensional perspective taking into consideration, in Kjellén's words, its topographical position, demography, history, laws etcetera. All these factors came to imply the need for serious studies able to properly account for each category in the organic state theory proposed by Kjellén.

Before leaving Kjellén it is of relevance to discuss two further elements of his taxonomy, eco-politics and demopolitics, as they relate to his geopolitics and his geographical imagination. In Staten som lifsform he tests four solutions to the question of how the people, as ethnos, is constituted as, in Ratzel's words, an "aggregate organism" (Bassin, 1987:477). The first solution Kjellén proposed was the genealogical, based on the idea of a pure racial ancestry. This solution was dispensed by Kjellén on the grounds provided by Ratzel. All nations are racially heterogeneous due to migration (Kjellén, 1916:85). The same was, according to Kjellén, true of the linguistic solution, since a people can, and does, sometimes change its language (Kjellén, 1916:89). The third solution, the psychological, was founded on the idea of a Herderian Volks Geist, a subjective, idealistic and free-floating notion 
of the nation that Kjellén argued against on the grounds that it didn't acknowledge the need to ground the people in the soil of the state (Kjellén, 1916:91). Finally, his own solution to the problem was based on a biological understanding of the nation. The nation was, for Kjellén, nothing less than an ethnic individual, a "makro-anthropos" or a "potenziertes Individuum" (Kjellén, 1916:92). Thus, for Kjellén there is a difference in degree between the state as nation and the state as people, in Kjellén's words: "The multitude [människomassa] that is connected solely by locality within a state we call people [folk] in a technical meaning. The mass [massa] that is connected by nationality we signify as nation" (Kjellén, 1916:84, my translation).

The element of Kjellén's eco-politics that I want to draw attention to is his discussion of autarky, specifically as it relates closely to his notion of geopolitics. Kjellén places the idea of autarky, self-sufficiency, in the context of, on one side, the state's topo-politics and fysio-politics and, on the other, to its socio-politics, particularly in relation to the states biopolitics and pletho-politics. The idea of a self-sufficient eco-politics is best understood in relation to Kjellén's notion that the state is an ethnic individual, creating from its multitude of people a degree of individuality. Furthermore, the same is true according to Kjellén when it comes to the state's geopolitics. The struggle for space that characterises history is for Kjellén: "nothing less than the striving of the state to become organic territories. They seek geographical individuals to which they can connect, and through those connections deepen their natural territory [gebit, in Swedish this word connotes ownership]. In order to reveal this relation, science first needs to clarify the concept 'geographical individual', which Karl Ritter formulated in 1817. A continuous series of observations has concluded that this concept is constituted by a dual movement: outwards 'natural boundaries', inwards harmonious context in a 'natural territory' [naturgebit]. The law of geographical individualisation has, in both directions, been more and more active in the life of states" (Kjellén, 1916:53, my translation). If this is true for the geopolitical and the ethno-political spheres the same is true for the state's eco-politics. The expression of this search for individuality is found in the state's level of autarky. The level of the state's autarky is in part given by its topo-politics and fysio-politics but Kjellén argues that: “...the state itself can affect its autarky. It is however not immediately given by the land; it has in its power the possibility to reshape the land, so that it better will live up to these demands. The autarky is only latent in the earth and needs to be released through labour; a forceful and systematic labour, intent on not only developing its predispositions but also complements its deficiencies, is an important contribution in the individuality of the country. The state is thus able to make its land more natural than it originally is" (Kjellén, 1916:61, my translation). Here we should notice that the conceptualisation of the state as a geographical individual, as defined by Ritter, doesn't correspond, as we have seen, with Ratzel's view that the vital state need to un- dergo incessant expansions (see Schultz, 1998). One way to explain Kjellén's recourse to Ritter is the fact that he was not arguing for a Swedish imperialism. Whereas that is precisely what Ratzel was doing in the German situation.

The Italian philosopher Roberto Esposito has identified a semantic shift in Kjellén's work. This shift occurs, argues Esposito, between Stormakterna and Staten som lifsform. While in the latter book Kjellén still conceives of the state as beholden to a constitutional framework, albeit connected to a geopolitics and ethno politics, in Staten som lifsform this constitutional framework is ceded to an organic and biopolitical framework, which is irreducible to a contractual or constitutional model of the state (Esposito, 2008:16). If we study Ratzel's Politische Geographie we can see that a kernel of this "originary nucleus of biopolitical semantics" is present already in Ratzel's analogy between the differentiation of the living organism and the spatial growth of the territory of the vital state. Furthermore, I would argue that this semantic shift should be read in relation to Kjellén's claim that his political taxonomy must be read as a unity or a totality, a totality that assembles the physical, anthropological, economical and biological elements of the state in a unifying organistic conception of the state. In Kjellén's work, the relation between the states autarky, its geographical individuality and its people has to be conceived as striving towards an isomorphic similitude, a similitude that, however, will always be lacking in that the relation between life and earth is not isomorphic but in a state of disequilibrium.

\section{Conclusions}

The genealogy of Lebensraum is not a straightforward affair. As we have seen the concept was first formulated as a response to Darwin's evolutionary hypothesis. After which it became inserted into Ratzel's project to synthesis biogeography and anthropogeography. Already in Ratzel we could see a semantic shift towards associating the Lebensraum with the idea of a vital state politics and a vital people. This semantic shift is, however, taken to fruition in Kjellén's formulation of an organic state theory in which the Lebensraum becomes the glue that holds the two key aspects of the state together the state's ethnopolitics and its geopolitics.

The paper has limited itself to tracing the formation of the Lebensraum concept through the works of the two most important figures behind its genesis, Friedrich Ratzel and Rudolf Kjellén. It can be argued that the proliferation of Lebensraum within a broader cultural and political discourse begins after the deaths of both men. Ratzel died in 1904 before he could complete the synthesis of his biogeographical and anthropogeographical work. Kjellén died in 1922, more or less at the same time as Karl Haushofer began publishing his Zeitschrift für Geopolitik (Natter, 2003).

It is with the ascendancy of Haushofer in the 1920s that the concept of Lebensraum reaches what we could call its 
mature stage (see further Haushofer, 1928a, b; Diner, 1999; Ebeling, 1994; Herwig, 1999). Expressed differently we can see, with the formation of Haushofer's school of geopolitics, how Lebensraum is operationalized in a wide range of different contexts. Haushofer's oeuvre cannot be described as adding to the conceptual formation of the Lebensraum concept. It can be argued that the contribution he gave, and for which he is still infamous, is directly connected to his desire to turn the Lebensraum discourse into state policy. Haushofer had in fact known Friedrich Ratzel when he was a boy in Munich and Ratzel was teaching there. Ratzel was a friend and colleague with Haushofer's father Max Haushofer who was also a professor at Munich's School of Higher Technical Studies (Herwig, 1999). It was also in Munich, though much later, that Haushofer came to know a young man by the name Rudolf Hess. The story is well known but it bears repeating. It was through this young man then, who came to work as Haushofer's assistant, that the General-cum-Professor was introduced to Adolf Hitler. I won't go into the full story of their relationship here but it is of relevance to recount a key passage that bears on the further translation of the Lebensraum concept. After the failed "beer-hall putsch" Hitler and Hess were found guilty of treason, sentenced to five years at Landsberg Fortress prison. In the end they served only eight months. Hitler later came to describe his incarceration at Landsberg as his "... university education at state expense" (quoted by Herwig, 2010:9). It was at Landsberg that the future Führer came to write Mein Kampf with Rudolf Hess as his personal secretary, taking dictation, and Haushofer as his personal tutor in, among other subjects, geopolitics and political geography (see further Barnes and Abrahamsson, 2012).

This series of men - Ratzel, Kjellén and Haushofer - is the familiar genealogy used to describe the formation of the concept of Lebensraum. I do not disagree with this argument, there are strong affinities and resemblances between the theories and practices of all three men. There are, however, adverse effects connected with the emphasis of a linear genealogy stretching from the Ratzelian Lebensraum, via Kjellén's organic state theory to Haushofer's operationalization in Geopolitik. I argue that this particular genealogy has failed to acknowledge a crucial operationalization of the concept of Lebensraum in relation to National socialist planning and ideology. I am talking, here, more specifically of the planning programs that were initiated by Heinrich Himmler's Reich's Commission for the Strengthening of Germandom, particularly the work conducted by Konrad Meyer and his associates at the Planning and Soil office of that organisation (Koehl, 1957). The aim of the Planning and Soil office was to provide the Third Reich with areal plans for its Eastern conquests, known as Generalplan Ost. That plan, according to Rössler (1990), was developed as a detailed policy for the settlement and administration of the newly acquired Eastern territories (see further Rössler and Schleiermacher, 1993; Barnes, 2012; Rössler, 1989; Burleigh, 1988; Kamenetsky, 1961). For Himmler, and other high-level Nazi- officials, the formulation of the Generalplan Ost was a step towards a larger reorientation and reformation of the German people (Rössler, 1990). In one sense the Generalplan Ost can be understood as the implementation of ideological ideas stemming from the more radical "green" wing of the Nazi-party - prominent among them were Richard Walther Darré, Gottfried Feder and Fritz Todt (Bramwell, 1985; Dahl, 2006). The operationalization of Lebensraum, in the context of the Generalplan Ost, is closely connected to the semantic shift identified by Esposito. Lebensraum thus came to function as a key element in the formation of the biocracy of the Nazi-state. More precisely, it came to function as a conceptual bridge between its thanatopolitics, reaching its zenith in the final solution, and the biopolitical policies aimed towards strengthening the German race (Esposito, 2008; Burleigh and Wippermann, 1991; Neumann, 2002; Mouton, 2007; Weiss, 2010). Furthermore, it is of importance to account for the divergent mobilisation of Lebensraum in Nazi policy if we are to better understand how certain elements of it actually never went away.

Acknowledgements. I am grateful to Benedikt Korf and Ola Söderström, without their astute comments and saintly patience this would be a much lesser paper. I also want to thank Trevor Barnes, Mark Bassin, Gunnar Olsson and Claudio Minca for conversations on the issues discussed in the paper.

Edited by: B. Korf

Reviewed by: two anonymous referees

\section{References}

Abrahamsson, C.: Review of "Vibrant Matter: A Political Ecology of Things", by Jane Bennett, Dialogues in Human Geography, 1, 399-402, 2011.

Barnes, T. J.: Notes from the underground: why the history of economic geography matters: the case of Central Place Theory, Econ. Geogr., 88, 1-26, 2012.

Barnes, T. J. and Abrahamsson, C.: No comedy, only tragedy: the Haushofers, father and son, and the spaces of Nazi geopolitics, RGS-IBG, Edinburgh, 2012.

Bassin, M.: Imperialism and the Nation State in Friedrich Ratzel's Political Geography, Prog. Hum. Geog., 11, 473-495, 1987.

Bramwell, A.: Blood and Soil: Richard Walther Darré and Hitler's "Green Party", Bourne End, Buckinghamshire, Kensal, 1985.

Burleigh, M.: Germany turns eastwards: a study of Ostforschung in the Third Reich, Cambridge University Press, Cambridge, 1988.

Burleigh, M. and Wippermann, W.: The Racial State, University of Cambridge Press, Cambridge, 1991.

Dahl, G.: Radikalare än Hitler? De esoteriska och gröna nazisterna. Inspirationskällor. Pionjärer. Förvaltare. Ättlingar., Atlantis, Malmö, 2006.

Danielsson, S.: Creating Genocidal Spaces: Geographers and the Discourse of Annihilation, 1880-1933, Space and Polity, 13, 5568, 2009.

Diner, D.: Knowledge of expansion on the geopolitics of Karl Haushofer, Geopolitics, 4, 151-88, 1999. 
Ebeling, F.: Geopolitik. Karl Haushofer und seine Raumwissenschaft 1919-1945, Akademie Verlag, Berlin, 1994.

Elvander, N.: Rudolf Kjellén och nationalsocialismen, Statsvetenskaplig tidskrift, 59, 15-41, 1956.

Esposito, R.: Bíos: Biopolitics and Philosophy, University of Minnesota Press, Minneapolis, 2008.

Gliboff, S.: H.G. Bronn, Ernst Haeckel, And The Origins Of German Darwinism: A Study in Translation and Transformation, MIT Press, Cambridge Mass, 2008.

Harrington, A.: Reenchanted Science: Holism in German Culture from Wilhelm II to Hitler, Princeton University Press, Princeton, 1996.

Haushofer, K.: Über die Historische Entwicklung des Begriffs Geopolitik, in: Bausteine zur Geopolitik, edited by: Obst, E., Kurt Vowinckel Verlag, Berlin, 3-28, 1928a.

Haushofer, K.: Grundlage, Wesen und Ziele der Geopolitik, in: Bausteine zur Geopolitik, edited by: Obst, E., Kurt Vowinckel Verlag, Berlin, 29-48, 1928b.

Haushofer, K. (Ed.): Jenseits der Grossmächte, Leipzig, B.G. Teubner, 1932.

Herwig, H.: Geopolitik, Haushofer, Hitler and Lebensraum, J. Strategic Stud., 22, 218-241, 1999.

Herwig, H.: The daemon of geopolitics: Karl Haushofer, Rudolf Hess, and Adolph Hitler, available at: http://www.usafa.edu/df/ dfh/docs/Harmon53.pdf (last access: 28 March 2013), 2010.

Holdar, S.: The Ideal State and the Power of Geography: The Life Work of Rudolf Kjellén, Polit. Geogr., 11, 307-323, 1992.

Kamenetsky, I.: Lebensraum in Hitler's War Plan: The Theory and the Eastern European Reality, Am. J. Econ. Sociol., 20, 313-326, 1961.

Kirchhoff, A.: Darwinismus angewandt auf Volker und Staaten, Heinrich Keller, Frankfurt, 1910.

Kjellén, R.: Studier öfver Sveriges politiska gränser, Ymer, 19, 183 331, 1899.

Kjellén, R.: Stormakterna: Konturer kring samtidens storpolitik, Hugo Grebers förlag, Stockholm, 1905.

Kjellén, R.: Staten som lifsform, Hugo Grebers förlag, Stockholm, 1916.

Kjellén, R.: Der Staat als Lebensform, S. Hirzel, Leipzig, 1917.

Kjellén, R.: Undersökningar till politikens system I, Statsvetenskaplig tidskrift, 22, 98-128, 1919a.

Kjellén, R.: Undersökningar till politikens system II, Statsvetenskaplig tidskrift, 22, 164-181, 1919b.

Kjellén, R.: Undersökningar till politikens system III, Statsvetenskaplig tidskrift, 22, 264-280. 1919c.

Koehl, R. L.: RKFDV: German Resettlement and Population Policy, 1939-1945: A History of the Reich Commission for the Strengthening of Germandom, Harvard University Press, 1957.

Livingstone, D. N.: Science, text and space: thoughts on the geography of reading, T. I. Brit. Geogr., 30, 391-401, 2005.

Mouton, M.: From Nurturing the Nation to Purifying the Volk: Weimar and Nazi Family Policy, 1918-1945, Cambridge University Press, Cambridge, 2007.

Natter, W.: Geopolitics in Germany, 1919-45: Karl Haushofer and the Zeitschrift für Geopolitik, in: The Companion to Political Geography, edited by: Agnew, J., Mitchell, K., and Toal, G., Blackwell, Oxford, 187-203, 2003.

Neumann, B.: The National Socialist Politics of Life, New German Critique, 85, 107-130, 2002.
Peschel, O.: Ursprung und Verschiedenheit der Menschenrassen, Das Ausland, 33, p. 393, 1860.

Ratzel, F.: Über den Lebensraum, eine biogeographische Skizze, Die Umschau, 21, 363-367, 1897.

Ratzel, F.: Der Lebensraum: Eine biogeographische Studie, in: Festgaben für Albert Schäffle zur siebenzigsten Wiederkehr seines Geburtstages am 24. Februar 1901, edited by: Bücher, K., Laupp, Tübingen, 1901.

Ratzel, F.: Politische Geographie, R. Oldenbourg, MünchenLeipzig, 1903 [1897].

Richards, R. J.: The Tragic Sense of Life: Ernest Haeckel and the Struggle over Evolutionary Thought, University of Chicago Press, Chicago, 2008.

Rössler, M.: Applied geography and area research in Nazi society: central place theory and planning, 1933-1945, Environ. Plann. D, 7, 419-431, 1989.

Rössler, M.: Wissenschaft und Lebensraum: Geographische Ostforschung im Nationalsozialismus, Dietrich Reimer Verlag, Hamburg, 1990.

Rössler, M. and Schleiermacher, S. (Eds.): Der "Generalplan Ost". Hauptlinien der nationalsozialistischen Planungs- und Vernichtungspolitik, Akademie Verlag, Berlin, 1993.

Schultz, H. D.: Herder und Ratzel: Zwei Extreme, ein Paradigma?, Erdkunde, 52, 127-143, 1998.

Smith, W. D.: Friedrich Ratzel and the Origins of Lebensraum, Ger. Stud. Rev., 3, 51-68, 1980.

Smith, W. D.: The Ideological Origins of Nazi Imperialism, Oxford University Press, New York, 1986.

Smith, W. D.: Politics and the Sciences of Culture in Germany, 1840-1920, Oxford University Press, New York, 1991.

Sprengel, R.: Kritik der Geopolitik Ein deutscher Diskurs 19141944, Akademie Verlag, Berlin, 1996.

Thermaenius, E.: Geopolitik och politisk geografi, Statsvetenskaplig tidskrift, 40, 213-328, 1937.

Thrift, N.: Intensities of Feeling: Towards a Spatial Politics of Affect, Geografiska Annaler, Series B, 86, 57-78, 2004.

Thrift, N.: Non-representational theory: Space, Politics, Affect, Routledge, London, 2007.

Troll, C.: Geographic Science in Germany during the Period 19331945: A Critique and Justification, Ann. Assoc. Am. Geogr., 39, 99-137, 1949.

Tunander, O.: Swedish-German Geopolitics for a New Century Rudolf Kjellén's “The State as Living Organism”, Review of International Studies, 27, 451-463, 2001.

Weikart, R.: Progress through Racial Extermination: Social Darwinism, Eugenics, and Pacifism in Germany, 1860-1918, Ger. Stud. Rev., 26, 273-294, 2003.

Weiss, S. F.: The Nazi Symbiosis: Human Genetics and Politics in the Third Reich, University of Chicago Press, Chicago, 2010.

Whatmore, S.: Hybrid Geographies: natures, cultures, spaces, Sage, London, 2002.

Whatmore, S.: Materialist returns: practising cultural geography in and for a more-than-human world, Cultural Geographies, 13, 600-610, 2006

Zimmerman, A.: Anthropology and Antihumanism in Imperial Germany, University of Chicago Press, Chicago, 2001. 